\title{
The effects of 17 alpha-estradiol to inhibit inflammation in vitro
}

\author{
Roberta S. Santos', Luciana A. de Fatima', Aaron P. Frank', Everardo M. Carneiro ${ }^{2 \dagger}$ and Deborah J. Clegg ${ }^{1 * \dagger}$
}

\begin{abstract}
Background: 17 Alpha-estradiol (17 a-E2) is a natural, non-feminizing stereoisomer of 17 beta-estradiol (17 $\beta-E 2)$. Whereas much is known about the physiological effects of $17 \beta-E 2$, much less is known about 17 a-E2. For example, $17 \beta$-E2 exerts anti-inflammatory effects in neurons and adipocytes through binding and activation of estrogen receptor alpha (ERa); however, if 17 a-E2 has similar effects on inflammation is currently unknown.

Methods: To begin to address this, we analyzed the ability of 17 a-E2 and $17 \beta-E 2$ to suppress lipopolysaccharide (LPS)-induced inflammation in vitro using embryonic fibroblast cells (MEF) from wild type and total body ERa (ERKO) male and female mice. Additionally, we further probed if there were sex differences with respect to the effects of E2s using primary pre-adipocyte cells from C57BL/6J male and female mice. Also, we probed mechanistically the effects of E2s in fully differentiated 3T3-L1 cells.

Results: Both E2s decreased LPS-induced markers of inflammation Tnf- $\alpha$ and II-6, and increased the anti-inflammatory markers II-4 and IL-6 receptor (II-6ra) in MEF cells. To begin to understand the mechanisms by which both E2's mediate their anti-inflammatory effects, we probed the role of ERa using two methods. First, we used MEF cells from ERKO mice and found reductions in ERa diminished the ability of 17 a-E2 to suppress Tnf- $a$ in female but not in male cells, demonstrating a sexual dimorphism in regard to the role of ERa to mediate 17 a-E2's effects. Second, we selectively reduced the expression of ERa in 3T3-L1 cells using siRNA and found reductions in ERa diminished the ability of both E2s to suppress Tnf- $a$ and II-6 expression. Lastly, to determine the mechanisms by which E2s reduce inflammation, we explored the role of NFkB-p65 and found both E2s decreased NFkB-p65 expression.
\end{abstract}

Conclusions: In conclusion, we demonstrate for the first time that 17 a-E2, as well as $17 \beta$-E2, suppresses inflammation through their effects on ERa and NFkB-p65.

Keywords: 17 Alpha-estradiol (17 a-E2), 17 Beta-estradiol (17 $\beta$-E2), Inflammation, Cell culture, Sexual dimorphism

\section{Background}

Estrogens play a crucial role in suppressing the development of chronic inflammatory diseases [1] and mitigating the impact of inflammation that occurs in diseases such as obesity and type II diabetes mellitus [2]. There is a wealth of information indicating that adipose tissues become inflamed in obesity, and adipose tissue inflammation is highly correlated with insulin resistance, cancer, and other metabolic sequelae associated with increased adiposity [3, 4]. Therefore, preventing or treating adipose tissue inflammation is undoubtedly important to prevent the development

\footnotetext{
* Correspondence: deborah.clegg@cshs.org

${ }^{\dagger}$ Equal contributors

'Biomedical Sciences Dept, Diabetes and Obesity Research Division,

Cedars-Sinai Medical Center, 8700 Beverly Blvd, Los Angeles, CA 90048, USA

Full list of author information is available at the end of the article
}

and slow the progression of metabolic diseases. Importantly, there appears to be a sexual dimorphism regarding the prevalence of diseases such as obesity, type II diabetes, and cardiovascular disease, with adult males presenting with a higher prevalence and enhanced disease risk when compared to adult females; however, following menopause, women become as susceptible as men to diseases associated with obesity [2]. Specifically, it has been demonstrated that loss of estrogens during the menopausal transition leads to increased expression and secretion of proinflammatory cytokines such as tumor necrosis factor-alpha (TNF- $\alpha$ ) and interleukin 6 (IL-6) [5].

Estrogens are a family of compounds that include 17 alpha-estradiol (17 $\alpha$-E2) as well as 17 beta-estradiol (17 $\beta$-E2). $17 \beta$-E2 is the main circulating and biologically 
most active form of estrogen [6,7], and it is well established that $17 \beta$-E2 decreases markers of inflammation [8]; however, the exact mechanisms by which it interferes with inflammatory processes are not fully understood. It appears that most of the anti-inflammatory effects of estrogens in non-reproductive tissues occur by activating estrogen receptors (ERs), mainly ERalpha (ER $\alpha)$ [9]. We have previously demonstrated that ER $\alpha$ is the predominant ER in the adipose tissue, and there are studies suggesting that ER $\alpha$ polymorphisms lead to adipose tissue accumulation, increased insulin resistance, and inflammation [10]. It has been shown that $17 \beta$-E2 binds ER $\alpha$ and inhibits the transcription of Tnf- $\alpha$ and Il-6 genes [11, 12]. In addition, through a transcriptional cross-talk between ER $\alpha$ and NFkappaB (NFkB), $17 \beta$-E2 inhibits the transcription of $\mathrm{Il}-6$ [13]. Furthermore, there are data to suggest that $17 \beta$-E2, in a nongenomic manner, can inhibit inflammation by modulating $\mathrm{NF} K \mathrm{~B}$ trafficking to the nucleus through activation of the PI3K/AKT pathway [14].

$17 \alpha-\mathrm{E} 2$ is a natural, non-feminizing isomer of $17 \beta-\mathrm{E} 2$ [15], and its mechanisms of action and function are relatively unknown. $17 \alpha$-E2 has been found in various tissues of adult male and female mice. Its concentrations are higher in the brain and adrenal glands compared to $17 \beta$ E2 and lower in the ovaries, uterus, and serum [16]. Currently, there are less data on the location and tissue content of $17 \alpha-\mathrm{E} 2$ in humans; however, there is evidence of endogenous $17 \alpha-E 2$ in the urine and serum of humans $[17,18]$. Importantly, $17 \alpha-\mathrm{E} 2$ is different from the synthetic compound mostly used in oral contraceptives and postmenopausal hormone therapy, $17 \alpha$-ethynylestradiol $[19,20]$; importantly, little is known about either of these estrogenic compounds and even less is known about their anti-inflammatory activities [21-24]. Recently, aged male mice fed a diet enriched in $17 \alpha$-E2 had reductions in body adiposity and markers of inflammation in plasma and adipose tissue [20], and there are data to suggest that $17 \alpha$-E2 may have neuroprotective effects [25]. $17 \alpha$-E2 appears to have the capacity to bind to ERs, but with lower affinity than $17 \beta$-E2 [26].

In contrast to $17 \alpha$-E2, $17 \beta$-E2 also has feminizing effects and can lead to uterine and ER-positive breast cancer in postmenopausal women [27-30]. Recently, Stout et al. (2017) [20] demonstrated reductions in inflammatory markers in adipose tissue in mice who were fed diets enriched in $17 \alpha$-E2. Since adipose tissue inflammation is key to the development of several diseases related to obesity, $17 \alpha$-E2 may be useful in treating metabolic disease, while avoiding the side effects of traditional $17 \beta$-E2 exposure. Here, we explored the anti-inflammatory effects of both E2s in vitro to begin to characterize the mechanisms which underlie the potential therapeutic benefit of $17 \alpha-\mathrm{E} 2$ for women and, possibly, men.

\section{Methods}

\section{Cell culture}

Briefly, mouse embryonic fibroblast (MEF) cells were generated from C57BL/6J WT and total body ER $\alpha$ knockout (ERKO) mice. ERKO mice were a gift from Pierre Chambon [31]. Embryos from WT and ERKO mice were harvested from two approximately 2-3-month-old dams, who were fed a chow diet optimized for breeding (\#2019, Harlan Teklad, Madison, WI). Mice were mated and conception was visually confirmed by the presence of a mating plug. Thirteen days after conception, dams were euthanized and embryos removed. Embryos were sacrificed by decapitation, and embryo heads were collected for genotyping. The embryos were then washed in sterile PBS, minced with a razor blade in $2 \mathrm{~mL}$ trypsin (025\%, Gibco). Following 5 min of incubation at $37{ }^{\circ} \mathrm{C}$, the minced tissue was pipetted up and down to produce a homogenous cell suspension. The homogenate was then incubated an additional $5 \mathrm{~min}$ at $37{ }^{\circ} \mathrm{C}$ and then evenly applied to a $50 \mathrm{~mL}$ petri dish containing $25 \mathrm{~mL}$ of culture media (DMEM High glucose medium with $10 \%$ FBS, $1 \%$ Pen/Strep, and $1 \mathrm{mM}$ NaPyr) and incubated at $37{ }^{\circ} \mathrm{C}$. Cells were passaged once they reached $\sim 90 \%$ confluency. Primary pre-adipocytes were generated as previously described [32].

MEF cells were cultured in DMEM no-phenol red (Thermo Fisher Scientific, Walhman, USA), supplemented with $10 \%$ charcoal: dextran stripped fetal bovine serum (FBS, Gemini Bio Products, Sacramento, USA), 1\% penstrep 10,000 U/ml (Thermo Fisher), and 1\% sodium pyruvate $100 \mathrm{mM}$ (Thermo Fisher). Primary pre-adipocytes were cultured in DMEM/F-12 with GlutaMAX phenol red (Thermo Fisher) supplemented with 10\% FBS and 1\% pen-strep 10,000 U/ml. 3T3-L1 cells were grown in DMEM phenol-red media (ATCC, Manassas, USA), supplemented with $10 \%$ Bovine calf bovine serum (ATCC) and 1\% pen-strep. After $48 \mathrm{~h}$ of confluency, DMEM was supplemented with methylisobutylxanthine (IBMX, 0.5 mM, Sigma, St Louis, USA), dexamethasone (1 $\mu \mathrm{M}, \mathrm{BD}$ Biosciences, San Jose, USA), and insulin $10 \mu \mathrm{g} / \mathrm{ml}$ (Sigma) [33], and serum was replaced FBS. Following $48 \mathrm{~h}$ of exposure, cells were cultured in DMEM supplemented only with insulin. For all cells, medium was replaced by DMEM no phenol-red supplemented with $10 \%$ charcoal: dextran stripped FBS $24 \mathrm{~h}$ before and during treatments.

Cells were treated for the indicated time with $17 \alpha-\mathrm{E} 2$ (Sigma) or $17 \beta$-E2 (Sigma) at $10 \mu \mathrm{M}$ concentration. Inflammation was induced by LPS at a concentration of $10 \mathrm{ng} / \mathrm{ml}$ (Sigma) either alone or in combination with the respective estrogen.

\section{RNAi in cell culture}

In this series of experiments, we used siRNA to knockdown Esr-1 (ER $\alpha$ gene) in the presence and absence of 
estrogens to determine if ER $\alpha$ mediates estrogens' effects on inflammation. To do this, 3T3-L1 cells were cultured in 12-well plates and transfected at day 10 of differentiation with siRNA targeting murine Esr-1 (siGENOME Mouse siEsr1, GE Dharmacon, Lafayette, USA, at the concentration of $100 \mathrm{nM}$ ). As a control, cells were treated with an unrelated control/scrambled sequence siRNA at the same concentration (siGENOME non-targeting siRNA, GE Dharmacon). Lipofectamine RNAi max was used as the transfection reagent (Thermo Fisher, at the concentration of $20 \mathrm{pM} / \mu \mathrm{l})$, according to the manufacturer's instructions. Seventy-two hours after siRNA transfection, cells were treated with estrogens and LPS as indicated, and then lysed for RNA extraction.

\section{Quantitative real-time PCR}

Relative expression of the pro-inflammatory genes Tumor Necrosis Factor Alpha (Tnf- $\alpha$ ); interleukin 6 (Il-6); and Nuclear Factor Kappa B Subunit 1 ( $\left.N f_{k} b 1\right)$, and antiinflammatory genes interleukin 4 (Il-4), and interleukin 6 receptor alpha (Il-6ro) were quantified following LPS and/ or E2s using qPCR. To determine the impact of treatments on ER $\alpha$, we also quantified Esr-1 gene expression. Cells were washed twice with PBS (Thermo Fisher) and lysed in $500 \mu \mathrm{l}$ of $\mathrm{TRIzol}^{\circ}$ reagent (Thermo Fisher). RNA from cells was extracted and isolated using the RNeasy kit (Qiagen, Germantown, USA), according to the manufacturer's instructions. The concentration and purity of RNA were determined by spectrophotometric analysis (NanoDrop ND-1000, Thermo Fisher), and all samples had a $\mathrm{A}_{260} / \mathrm{A}_{280}$ ratio around 2.0 [34]. Total cDNA was synthesized using the High Capacity cDNA Reverse Transcription kit (Applied Biosystems, Foster City, USA). Real-time qPCR was performed using Taqman Universal Mastermix II (Applied Biosystems) and Taqman specific primers, on the QuantStudio $12 \mathrm{~K}$ Flex Real-Time PCR System. Mouse Gapdh was used as reference gene, and data was normalized and relative expression determined using $2^{-\Delta \Delta \mathrm{CT}}$ method.

\section{Western blotting}

We determined total protein levels of $E R \alpha$, as well as protein levels and cellular location of $\mathrm{NF}_{\mathrm{K}} \mathrm{B}$ p65. NFKB fractions in the cytosol or nucleus were normalized to total NFkB expression. Briefly, for total protein, $150 \mu \mathrm{l}$ of RIPA buffer (Thermo Fisher), supplemented with anti-phosphatase cocktail (PhosphoSTOP Easy pack, Sigma) and anti-protease cocktail (Complete mini protease inhibitor, Sigma), was used per well. After sample centrifugation, the supernatant was separated and used to quantify protein concentration and prepare samples for gel electrophoresis and Western blotting. For cell fractionation, the protocol adapted from Silva et al. (2005) [35] was used.
Protein concentrations were determined by BCA (Thermo Fisher). Proteins $(30-50 \mu \mathrm{g})$ were separated by electrophoresis (Bio-Rad, Hercules, USA) and electrotransferred to nitrocellulose membrane (Trans-turbo transfer pack, Bio-Rad). Non-specific binding sites were saturated by incubation of membranes for $1 \mathrm{~h}$ in TBS (supplemented with 1\% Tween 20) and 5\% non-fat powdered milk, followed by overnight incubation with primary antibodies (NFkB p65, Sc8008, St Cruz Biotechnology, Dallas, USA; ER $\alpha$, Sc542, St Cruz, at the concentration of 1:1000). Appropriate secondary antibodies were used (Goat anti-mouse, SeraCare Life Sciences, Milford, USA, or Goat anti-rabbit, SeraCare, at the concentration of 1:10,000), followed by enhanced chemiluminescence assay (Bio-Rad). The optical density of blots was analyzed using ImageLab software (Bio-Rad), and $\beta$-actin (Sc1615, St Cruz) or histone (Sc10809, St Cruz) were used for normalization. The results were expressed as arbitrary units in comparison to the control group, which was set as 1.0.

\section{Immunofluorescence}

In this series, we verified protein expression and location of NFkB p65 and ER $\alpha$. To do this, cells were fixed with $4 \%$ paraformaldehyde and permeabilized with $0.5 \%$ saponin. Cells were stained for primary antibodies $\mathrm{NF}_{\kappa} \mathrm{B}$ p65 or ER $\alpha$ overnight (at the concentration of 1:50), and then incubated with fluorescent-labeled secondary antibody (Goat to mouse-Alexa Fluor, ab150116, Abcam, Cambridge, USA; Goat to rabbit- FITC, ab6717, Abcam, at the concentration of 1:200), followed by DAPI incubation. Slides were mounted with Vectashield (Vector Laboratories, Burlingame, USA). Images were captured using Keyence ${ }^{\circ}$ BZ-9000 microscope and analyzed by Keyence ${ }^{\bullet}$ BZ-9000 software.

\section{Statistical analysis}

Data is presented as mean \pm SEM of three independent experiments. For primary cells, two mice were pooled and processed for each experiment, which yielded three biological replicates [36, 37]. Statistical analysis was performed with GraphPad Prism version 6.0 for Windows (GraphPad software, San Diego, CA, USA). One-way ANOVA followed by Tukey post-test comparisons and two-tailed paired Student's test were used as appropriate. $P<0.05$ was considered statistically significant.

\section{Results}

$17 \alpha$-E2 and $17 \beta$-E2 attenuated LPS-induced inflammatory markers in both male and female MEF cells

To begin to address the role of estrogens (E2s) on inflammatory markers in vitro, we directly applied $17 \alpha$-E2 and 17 $\beta$-E2 to mouse embryonic fibroblast (MEF) cells derived from male and female C57BL/6J mice. To induce inflammation, MEFs were treated with LPS followed by the two 
different estrogens. First, to determine if estrogens are able to suppress LPS-induced inflammation, cells were pretreated overnight (12 h) with estrogens, followed by a 2 -h LPS treatment. In an additional series of experiments to determine if estrogens are able to suppress LPS-induced inflammation with shorter exposure, cells were pre-treated with E2s for only $1 \mathrm{~h}$, followed by $2 \mathrm{~h}$ LPS treatment. Long pre-exposure to $17 \alpha$-E2 or $17 \beta$-E2 prevented LPSinduced inflammation as demonstrated by reductions in Tnf- $\alpha$ mRNA expression in both male and female cells; however, following the short-term exposure, only $17 \alpha$-E2 was capable of reducing $\operatorname{Tn} f-\alpha$ in both sexes (Fig. 1a, b). Interestingly, the longer exposure to E2s did not attenuate LPS-induced $I l-6$ expression in female cells, but did in male cells; whereas, shorter exposure of both E2s decreased $\mathrm{Il}-6$ in both female (Fig. 1c) and male cells (Fig. 1d).
To begin to determine the role of ER $\alpha$ to mediate E2s' effects on inflammation, MEF cells were generated from mice lacking ER $\alpha$ (ERKO) and were tested using a similar paradigm (Fig. 2a, b, 3a, b). ERKO cells at baseline had higher markers of Tnf- $\alpha$ and Il-6 genes both in male (Fig. 2c-f) and female (Fig. 3c-f) cells when compared to wild type, control cells. In male ERKO cells, $17 \alpha$-E2 treatment reduced LPS-induced Tnf- $\alpha$ and $I l-6$ expression, indicating $17 \alpha$-E2 might activate other ERs to reduce inflammatory markers in male cells (Fig. 2c-f). In female ERKO cells, 17 $\alpha$-E2 treatment reduced LPS-induced Il- 6 but not Tnf- $\alpha$ expression (Fig. 3c-f), indicating the ability of $17 \alpha-\mathrm{E} 2$ to decrease Tnf- $\alpha$ gene expression depends on ER $\alpha$ only in female cells. These intriguing data strongly support the hypothesis that male and female cells differ with respect to their response to $17 \alpha-\mathrm{E} 2$ to modulate inflammation, and ER $\alpha$ might modulate $17 \alpha$-E2's effects only in female cells.

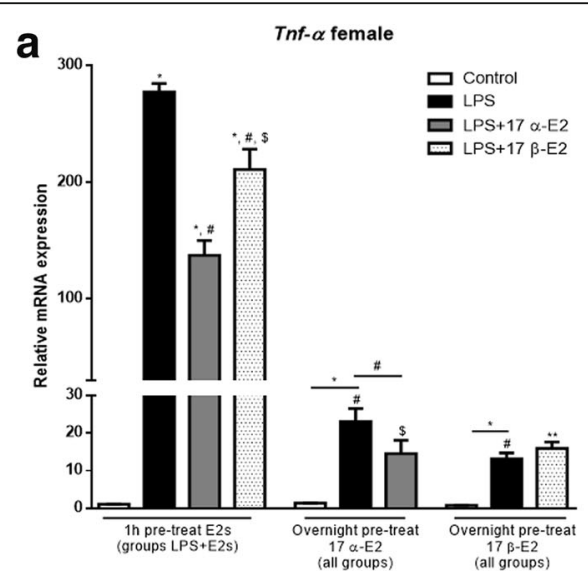

b
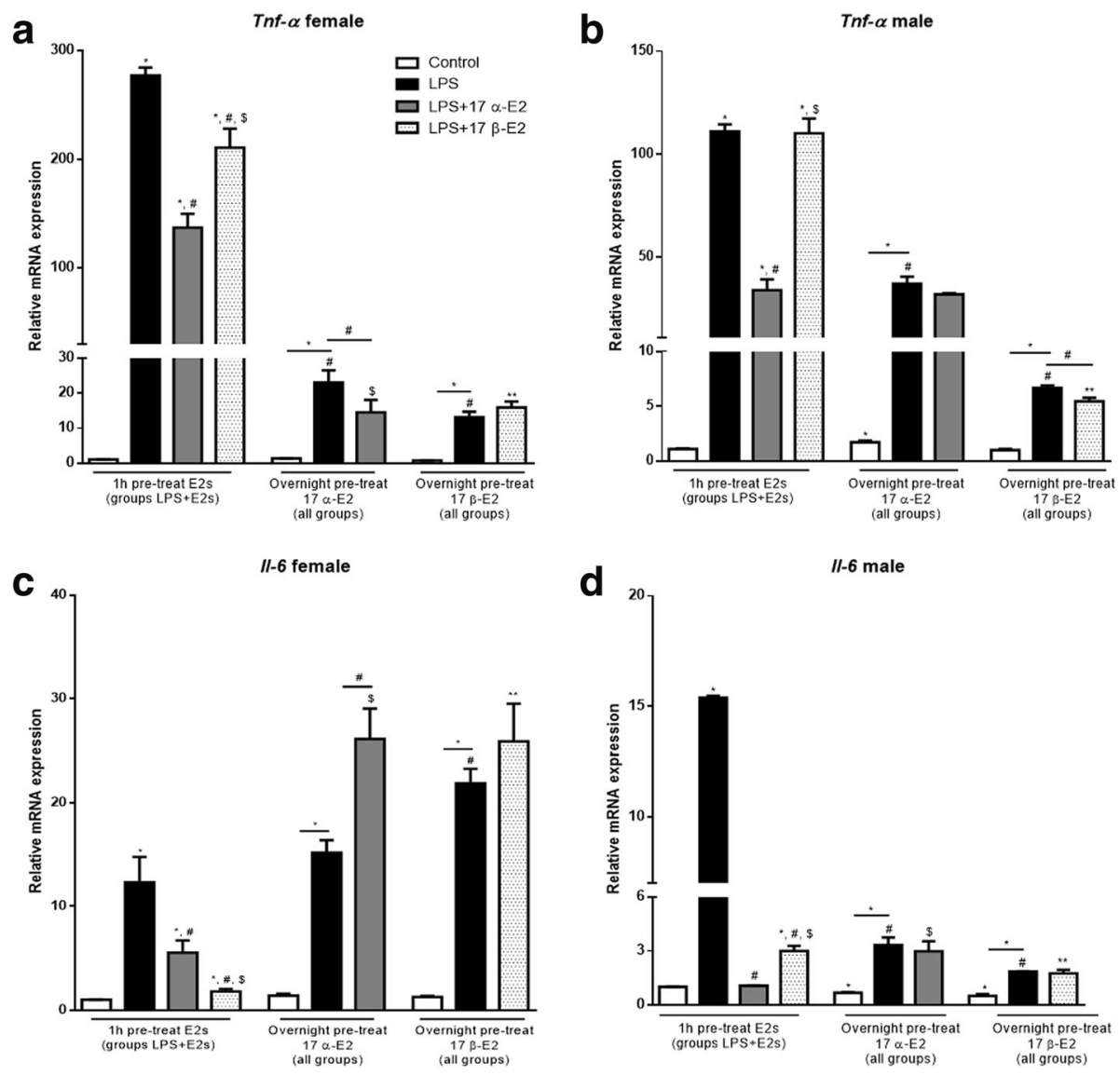

Fig. 1 Effects of 17 a-E2 and 17 -E2 on mouse embryonic fibroblast (MEF) cells derived from C57BL/6J female and male mice. a Cells were pre-treated with vehicle (control and LPS groups) or estrogens for $1 \mathrm{~h}$ (LPS $+17 \mathrm{a}-\mathrm{E} 2$ and LPS $+17 \beta-E 2$ groups). Following which, the media was changed to either new media plus LPS (LPS group), or LPS + 17 a-E2 (LPS + 17 a-E2 group), or LPS + $17 \beta-E 2$ (LPS + $17 \beta-E 2$ group) for $2 \mathrm{~h}$. b All groups were pre-treated overnight (approximately $12 \mathrm{~h}$ ) with $17 \mathrm{a}$-E2 (control, LPS, and LPS $+17 \mathrm{a}$-E2 groups). Media was replaced on the next day by new media supplemented with LPS (LPS groups), or LPS + 17 a-E2 (LPS + 17 a-E2 group) for $2 \mathrm{~h}$. c All groups were pre-treated overnight (approximately $12 \mathrm{~h}$ ) with $17 \mathrm{\beta}$-E2 (control, LPS, and LPS $+17 \beta$-E2 groups). Media was replaced on the next day by new media supplemented with LPS (LPS groups), or LPS $+17 \beta$-E2 (LPS $+17 \beta$-E2 group) for $2 \mathrm{~h}$. Relative mRNA expression of Tnf- $a(\mathbf{a}-\mathbf{b})$, and II- $6(\mathbf{c}-\mathbf{d})$. Data are presented as mean \pm SEM values. Asterisk indicates $P<0.05 \times$ control group (C). Pound indicates $P<0.05 \times$ LPS group. Dollar sign indicates $P<0.05 \times$ LPS +17 a-E2 group. Two asterisks indicates $P<0.05 \times$ LPS $+17 \beta$-E2 group ( $n=3$ independent rounds of cells) 

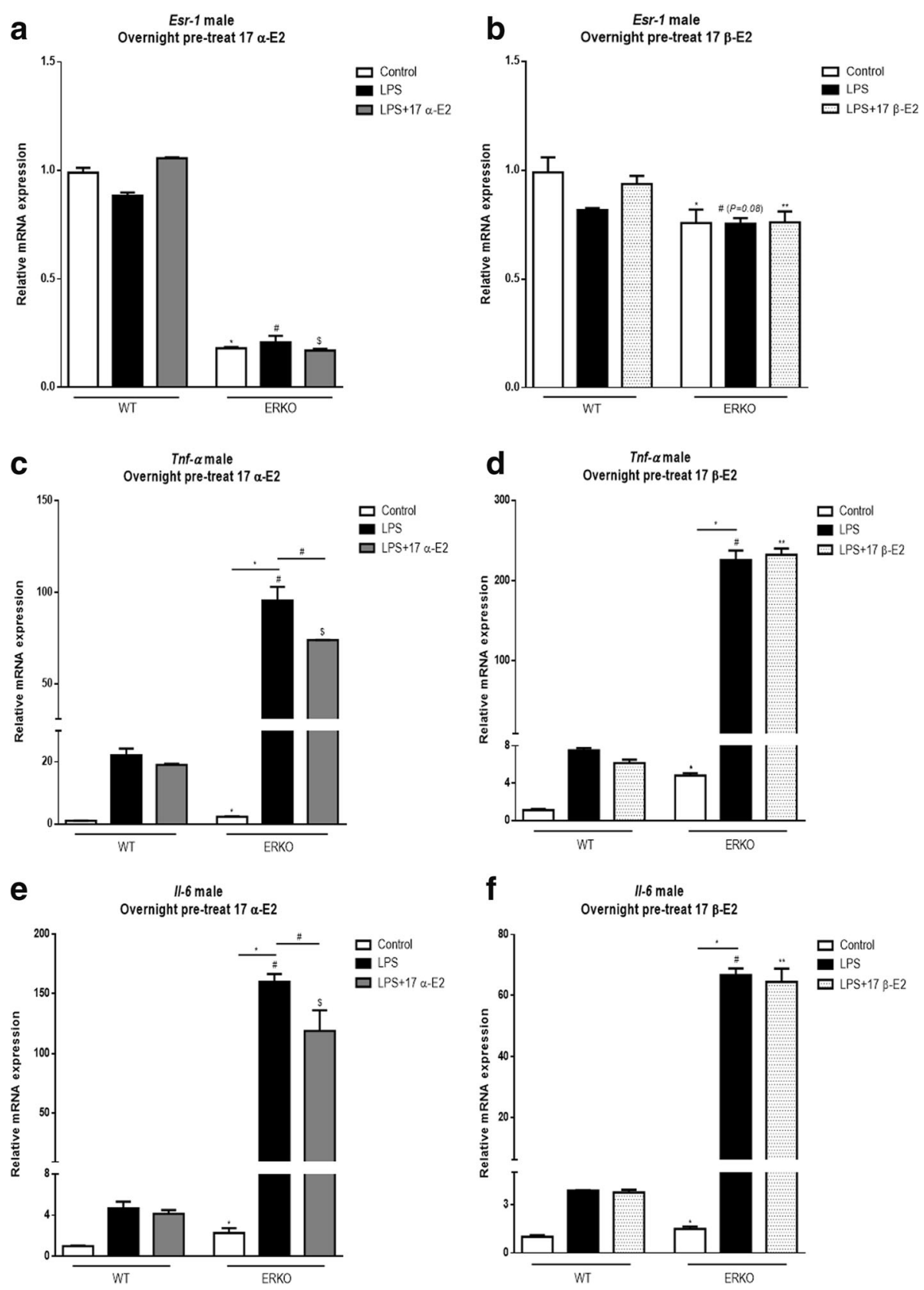

Fig. 2 Effects of 17 a-E2 and 17 -E2 on mouse embryonic fibroblast (MEF) cells derived from C57BL/6J WT and ERKO male mice pre-treated overnight with $17 \mathrm{a}-\mathrm{E} 2$ ( $\mathrm{A}, \mathrm{C}$, and E), or $17 \mathrm{\beta}-\mathrm{E} 2(\mathrm{~B}, \mathrm{D}$, and E) for $12 \mathrm{~h}$, followed by $2 \mathrm{~h}$ LPS. Relative mRNA expression of Esr-1 (a-b), Tnf-a (c-d), and II-6 (e-f). Data are presented as mean \pm SEM values. Asterisk indicates $P<0.05 \times$ control group (C). Pound indicates $P<0.05 \times$ LPS group. Dollar sign indicates $P<0.05 \times$ LPS +17 a-E2 group. Two asterisks indicates $P<0.05 \times$ LPS $+17 \beta$-E2 group $(n=3$ independent rounds of cells)

$17 \alpha-E 2$ and $17 \beta-E 2$ attenuated LPS-induced inflammatory markers in primary pre-adipocytes derived from male and female mice

Since the effects of $17 \alpha$-E2 to modulate inflammatory markers were more pronounced in the short-term exposure in MEF cells, we further investigated its effects on primary pre-adipocytes using this protocol. Primary pre-adipocytes were extracted from $\mathrm{C} 57 \mathrm{BL} / 6 \mathrm{~J}$ male and female mice; at baseline, male cells had higher expression of Tnf- $\alpha$ and Il-6 when compared to females (Fig. 4a, b). $17 \beta$-E2 reduced LPS-induced inflammatory markers in both male and female cells. Following LPS exposure, $17 \alpha-$ E2 decreased Tnf- $\alpha$ expression in male but not in female cells (Fig. 4a). Therefore, in a more developed model of adipose tissues (primary pre-adipocyte cells), $17 \alpha$-E2 was able to reduce $\mathrm{Il}-6$ in cells derived from both sexes, but it 

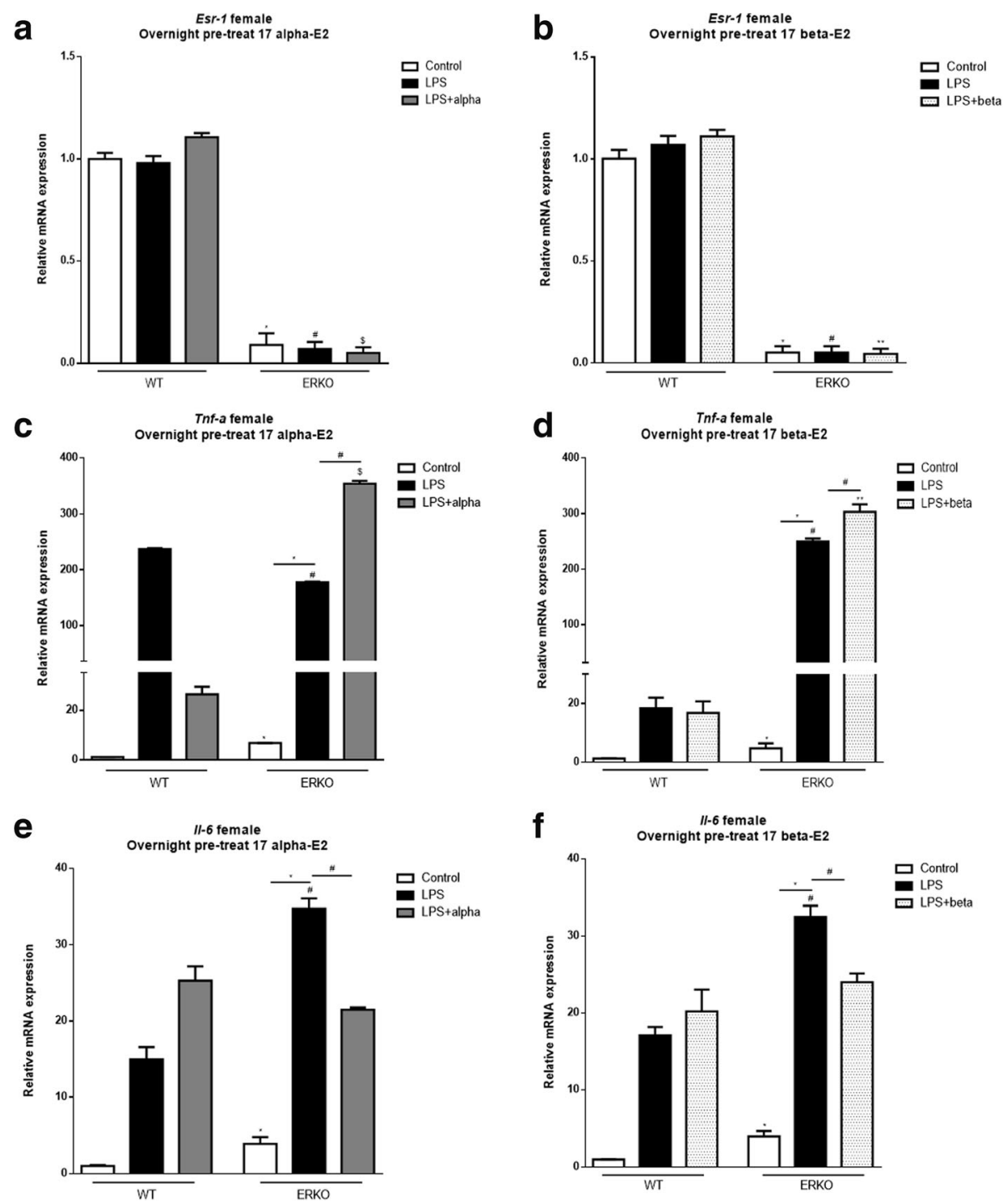

Fig. 3 Effects of $17 \mathrm{a}$-E2 and $17 \beta$-E2 on mouse embryonic fibroblast (MEF) cells derived from C57BL/6J WT and ERKO female mice pre-treated overnight with $17 \mathrm{a}-\mathrm{E} 2(\mathrm{~A}, \mathrm{C}$, and E), or $17 \beta-\mathrm{E} 2(\mathrm{~B}, \mathrm{D}$ and $\mathrm{E})$ for $12 \mathrm{~h}$, followed by $2 \mathrm{~h}$ LPS. Relative mRNA expression of Esr-1 (a-b), Tnf-a (c-d), and II-6 (e-f). Data were presented as mean \pm SEM values. Asterisk indicates $P<0.05 \times$ control group (C). Pound indicates $P<0.05 \times$ LPS group. Dollar sign indicates $P<0.05 \times$ LPS +17 a-E2 group. Two asterisks indicates $P<0.05 \times$ LPS $+17 \beta$-E2 group $(n=3$ independent rounds of cells)

decreased Tnf- $\alpha$ only in male cells. Male cells presented lower levels of Esr1 expression than female cells (Fig. 4c); consistent with our previous ERKO MEF data, this suggests $17 \alpha$-E2 might activate other ERs to reduce inflammation in males.

$17 \alpha-E 2$ and $17 \beta-E 2$ attenuated LPS-induced inflammatory markers in differentiated 3T3-L1 adipocytes in an ERadependent manner

In 3T3-L1 fully differentiated adipocytes, we confirmed that the treatments with LPS and E2s were not altering the viability of the cells (Additional file 1: Figure S1a, b). Consistent with our previous results, LPS treatment increased mRNA expression of Tnf- $\alpha$ and $I l-6$, while both E2s decreased LPS-induced Tnf- $\alpha$ and Il-6 expression (Fig. $5 \mathrm{a}, \mathrm{b}$ ). To begin to assess if this was unique to these two inflammatory markers, we also probed for $N f \kappa b 1$ and Rela, additional inflammatory markers within the NFкB family. Consistently, we found that E2s reduced expression of these markers (Fig. 5c, d). Additionally, both E2s increased $I l-4$ and $I l-6 r a$ mRNA, markers of anti-inflammatory pathway induction (Fig. 5e, f).

Since the ERKO mouse lacks Esr-1 gene expression in all tissues from the beginning of its embryonic development, we repeated our study by selectively knocking down Esr-1 from fully differentiated adipocytes. Fully differentiated 3T3-L1 adipocytes were transfected with specific siRNA for Esr-1, which reduced Esr-1 mRNA expression 


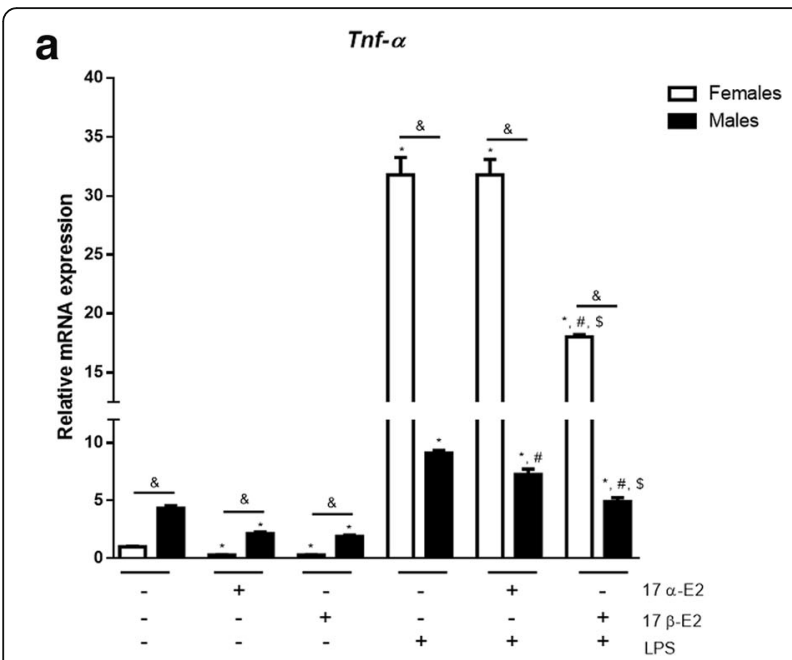

b<smiles>[AlH2]</smiles>

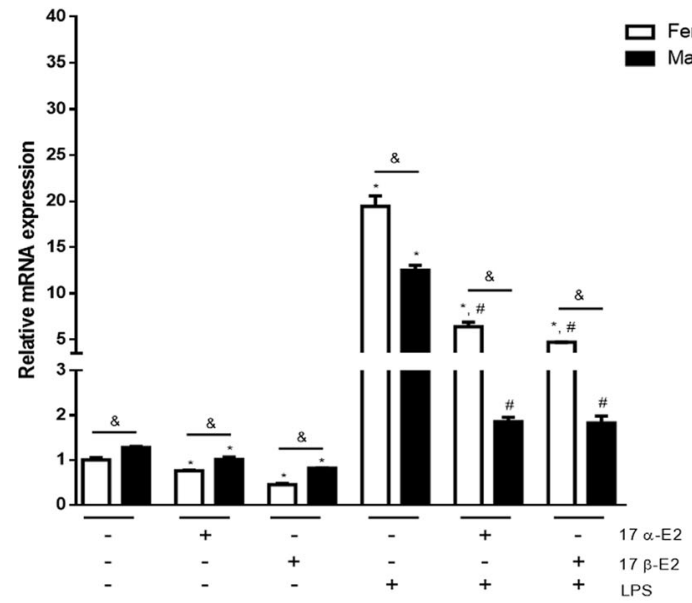

C

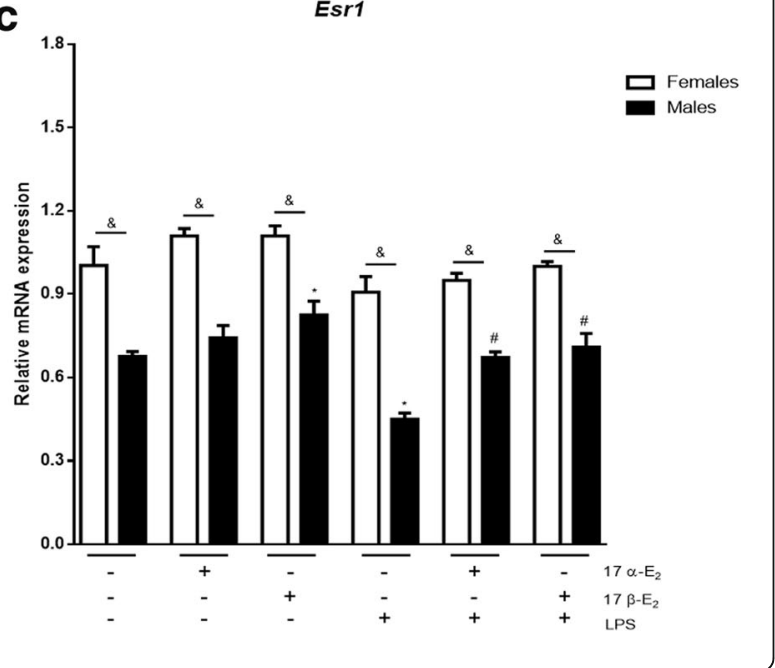

Fig. 4 Effects of $17 \alpha-E_{2}$ and $17 \beta-E_{2}$ on modulation of LPS-induced inflammatory markers in primary pre-adipocyte cells derived from C57BL/6J female and male mice. Cells were pre-treated with E2s for $1 \mathrm{~h}$, followed by $2 \mathrm{~h}$ LPS treatment. Relative mRNA expression of Tnf-a (a), II-6 (b), and Esr1 (c). Data are presented as mean \pm SEM values. Asterisk indicates $P<0.05$ compared to control group (C). Pound indicates $P<0.05 \times$ LPS group. Dollar sign indicates $P<0.05 \times$ LPS +17 a-E2 group. Ampersand indicates $P<0.05 \times$ females. $(n=3$ independent rounds of cells)

and protein (Additional file 2: Figure S2). Consistent with our hypothesis, knocking down Esr1 resulted in higher levels of Tnf- $\alpha$ and Il-6 in all groups. Furthermore, following knockdown of ER $\alpha, E 2 s$ were not able to decrease markers of inflammation to the same level (Fig. 6a-d).

$17 \alpha-E 2$ and $17 \beta$-E2 attenuated LPS-induced inflammatory markers through decreased NFKB-p65 and increased ERa protein expression

When stimulated, NFkB-p65 translocates to the nucleus and initiates the transcription of pro-inflammatory genes. To begin to investigate the mechanisms involved in E2mediated reductions in inflammation, nuclear and cytoplasmic p65 protein levels were determined. Consistent with previous reports, LPS increased nuclear translocation of p65; however, here, we provide data suggesting neither isoform of E2 influenced translocation (Fig. 7a). Importantly, however, we did find that total protein levels of p65 were suppressed by both E2s (Fig. 7b), which was further demonstrated by immunofluorescence (Fig. 7c). Interestingly, LPS decreased ER $\alpha$ protein expression, whereas both estrogens prevented LPS-mediated decreases in ER $\alpha$ protein expression (Fig. 7d, e).

\section{Discussion}

There is epidemiological evidence suggesting that estrogens protect against the development of chronic inflammatory diseases. This is further supported by the fact that following menopause, when circulating estrogens diminish, there is a concomitant increase in pro-inflammatory cytokines [8]. 17 Beta-estradiol (17 $\beta$-E2) has been well established as one of the estrogens that is responsible for mediating these antiinflammatory effects [38-40], and this may be therapeutically important because both systemic inflammation, as well as inflammation within adipose tissues, mediates many of the comorbidities associated with obesity [3, 4, 14]. Critically, there are data demonstrating that $17 \beta$-E2 decreases inflammation directly within adipose tissues [41, 42].

17 Alpha-estradiol (17 $\alpha$-E2) is a natural, non-feminizing isomer of $17 \beta$-E2 $[15,20]$, and recently, there have been reports that $17 \alpha$-E2 reduces inflammation in aged male mice [20]. Therefore, since $17 \alpha-\mathrm{E} 2$ is non-feminizing, it is important to determine if this could be used as an antiinflammatory agent that would provide benefit without 
a

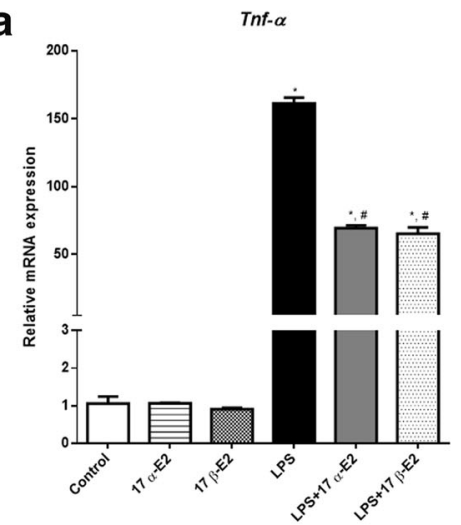

C

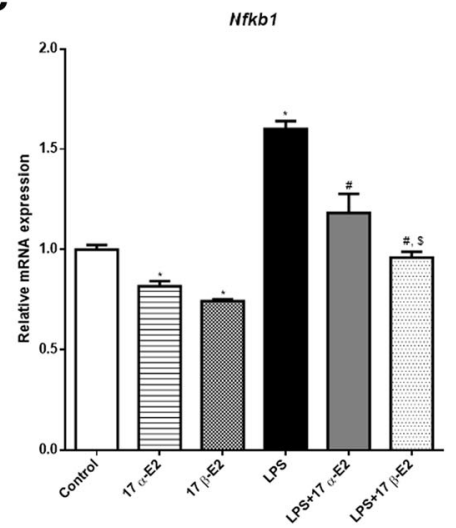

e

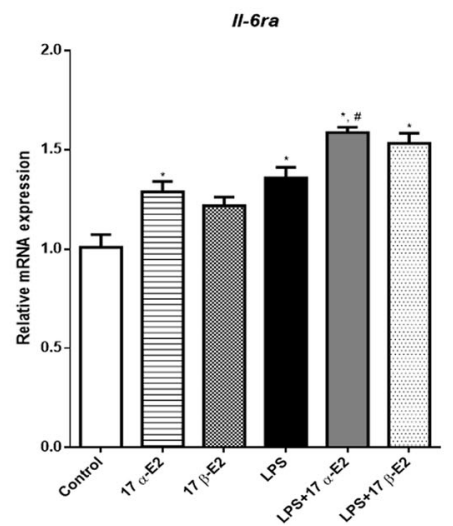

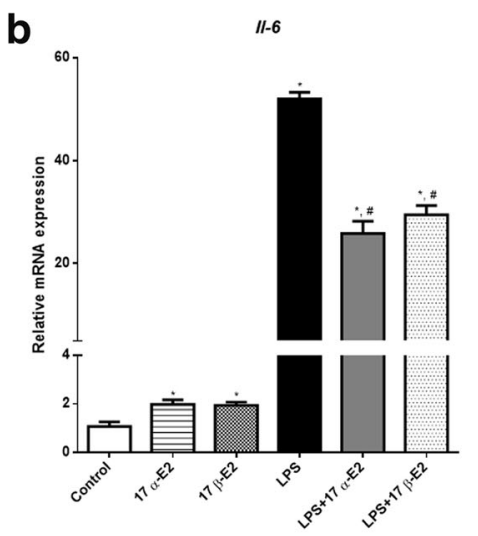

d

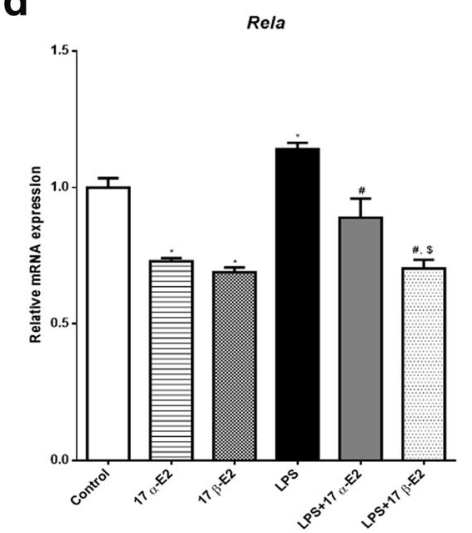

f

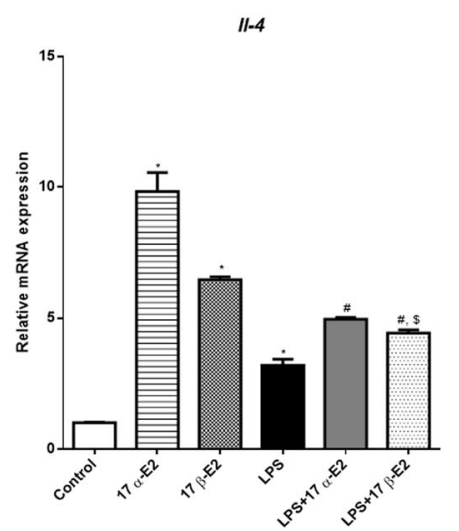

Fig. 5 Effects of 17 a-E2 and $17 \beta$-E2 on modulation of inflammatory markers in 3T3-L1 differentiated cells. Relative mRNA expression of Tnf-a (a), II-6 (b), Nfkb1 (c), Rela (d), II-6ra (e), and II-4 (f). Data are presented as mean \pm SEM values. Asterisk indicates $P<0.05$ compared to control group (C). Pound indicates $P<0.05 \times$ LPS group. Dollar sign indicates $P<0.05 \times$ LPS +17 a-E2 group. $(n=3$ independent rounds of cells $)$

causing the negative/secondary effects of estrogen supplementation, such as uterine or breast cancer [27-30]. Here we extend our knowledge of the role of $17 \alpha$-E2 in modulating inflammation by directly looking at its impact in adipocyte-like cells. Our data support previous findings with respect to $17 \alpha$-E2's ability to suppress inflammation within these tissues [20]. Additionally, we found that there may be a sexually dimorphic effect of $17 \alpha$-E2, with males being more sensitive to its effects.
We and others have reported an important role for $E R \alpha$ in modulating inflammatory responses in various tissues [9, 42]. Additionally, we have previously demonstrated that ER $\alpha$ is the predominant ER in the adipose tissue, and there are studies suggesting that ER $\alpha$ polymorphisms lead to adipose tissue accumulation, increased insulin resistance, and inflammation [10]. When we knocked down ER $\alpha$ expression in 3T3-L1 adipocytes, levels of inflammatory markers significantly increased. These data suggest the 
a

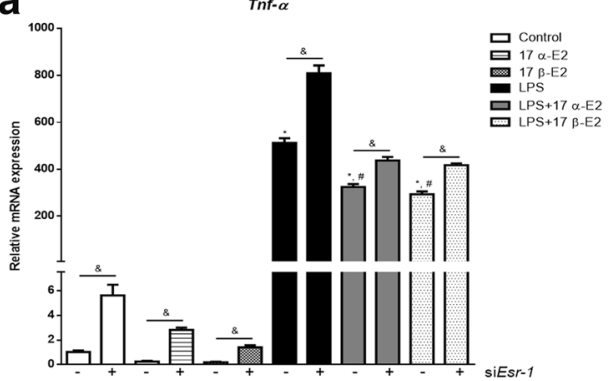

C

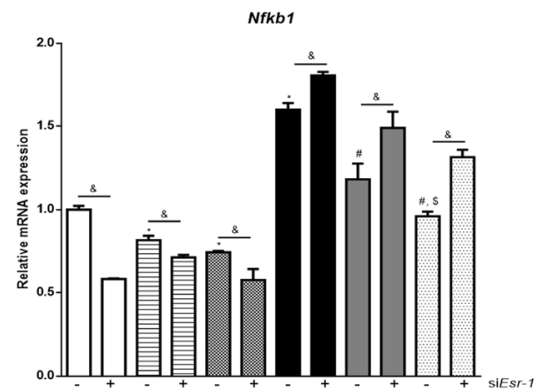

b

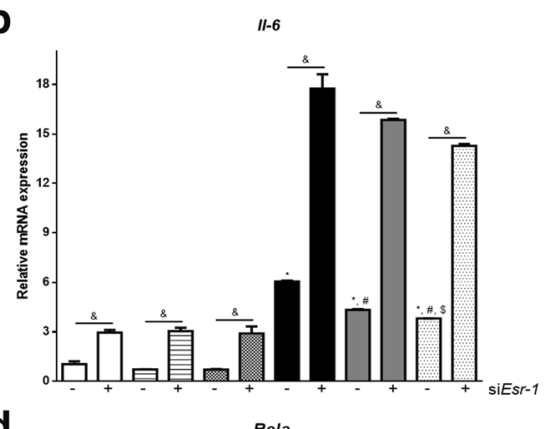

d

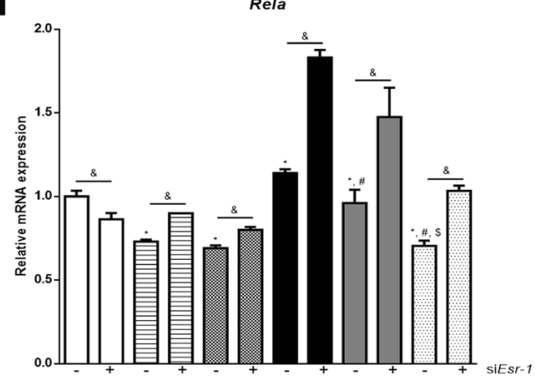

Fig. 6 Effects of Esr1 silencing on inflammatory markers gene expression in differentiated 3T3-L1 adipocytes. Esr1 gene was silenced using siRNA, and cells were collected $72 \mathrm{~h}$ after silencing. Relative mRNA expression of Tnf- $a(\mathbf{a}), \| 1-6$ (b), Nfkb1 (c), and Rela (d). Data are presented as mean \pm SEM values. Asterisk indicates $P<0.05$ compared to control group (C). Pound indicates $P<0.05 \times$ LPS group. Dollar sign indicates $P<0.05 \times$ LPS +17 a-E2 group. Ampersand indicates $P<0.05 \times$ siRNA group. $(n=3$ independent rounds of cells $)$

ability of $17 \alpha$-E2 to decrease markers of inflammation depends on ER $\alpha$. The importance of ER $\alpha$ was further substantiated by our finding that LPS both suppresses the expression of ER $\alpha$ and induces inflammation, suggesting that one of the mechanisms by which inflammation is induced by LPS is through suppression of ER $\alpha$. Importantly, it appears there is a sexual dimorphism regarding which ER mediates $17 \alpha$-E2's effects on inflammatory markers. In contrast to what appears to be true for female cells, in males, there may be a different mechanism as it appears that ERs other than ER $\alpha$ may modulate $17 \alpha$-E2's effects, such as ER $\beta$ and GPER30 (Additional file 3: Figure S3 and Additional file 4: Figure S4).

We have not specifically tested competitive binding of the ERs following exposure to differing E2s; however, reports indicate that $17 \alpha$-E2 and $17 \beta$-E2 possess different affinities for ERs. According to Edwards and McGuire (1980) [43], there are variations in $17 \alpha$-E2's relative binding affinity to ERs that could range from as low as $1 \%$ of $17 \beta$-E2 in rat uterus to values reaching $90 \%$ in mouse uterus. Other investigators have found diverse affinities, as well: Kuiper et al. (1997) [44] reported an affinity of $17 \alpha$ $E 2$ to ER $\alpha$ of $58 \%$ of the relative affinity of $17 \beta$-E2, and $11 \%$ to ER $\beta$, while Torand-Allerand et al. (2005) [26] reported an affinity of $17 \alpha$-E2 binding to human recombinant ER $\alpha$ and ER $\beta$ of 51 and 64\% compared to $17 \beta$-E2, respectively. Kaur et al. (2015) [45] indicated an affinity of $17 \alpha$-E2 to ER $\alpha$ to be 40 -times lower than $17 \beta$-E2. These reports suggest that in an environment where both E2s are present (as is the case in humans and mice in vivo), competition for ER binding may occur; however, since 17 $\beta$-E2 has higher binding affinity to both ERs, it tends to exert more biological activity. We suggest there may be physiological benefit in applying $17 \alpha$-E2 to reduce inflammatory markers when the levels of $17 \beta$-E2 are reduced, such as in males and postmenopausal (post- oophorectomy) females.

NFkappaB (NFkB) is included within in the inflammatory cascade. Its inactive form resides in the cytoplasm, bound to IKappaB (ІкB). When it is activated by a stimulus, IкB is phosphorylated by IKappaK (IкK) and dissociates from $\mathrm{NF} \kappa \mathrm{B}$. NFkB then heterodimerizes and translocates to the nucleus, where it binds and modulates expression of target genes such as Tnf- $\alpha$ and Il-6. Estrogen receptors (ERs) can repress $\mathrm{NFkB}$ activity through diverse mechanisms. In the study of Quaedackers et al. (2001) [46], the osteoblastic cell line U2-OS was transfected with a $\mathrm{NFKB}_{\mathrm{K}}$ reporter in combination with an expression vector encoding ER $\alpha$ or $E R \beta$. Co-transfection with ER $\alpha$ resulted in repression of the TNFo-induced transcriptional activity of NFkB; however, co-transfection of ER $\beta$ resulted in upregulation of TNF $\alpha$ induced $\mathrm{NFK}_{\mathrm{K}} \mathrm{B}$ activity in the absence of a ligand, leading to upregulation of NFKB-regulated genes, which suggests that the hormone-independent ER repression of $\mathrm{NFKB}_{\mathrm{B}}$ is receptor-specific to ER $\alpha$. Sun et al. (1998) [47] transfected HeLa-ER ${ }^{+}$cells with a construct containing the IL-6 promoter linked to the luciferase gene $\mathrm{NF \kappa B} \mathrm{p} 65$ or $\mathrm{NF \kappa B} \mathrm{p} 50$ with ІкB $\alpha$ or control expression vector. The transfection of 

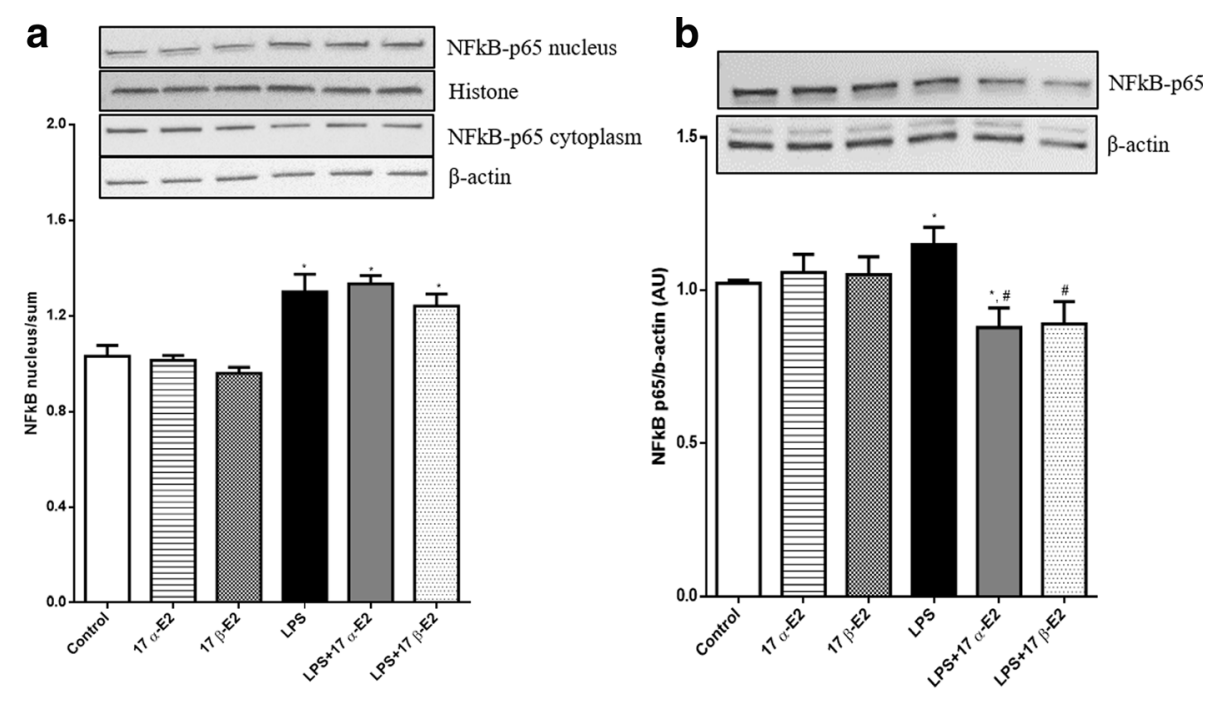

C

$17 \alpha-\mathrm{E} 2$

$17 \beta$-E2
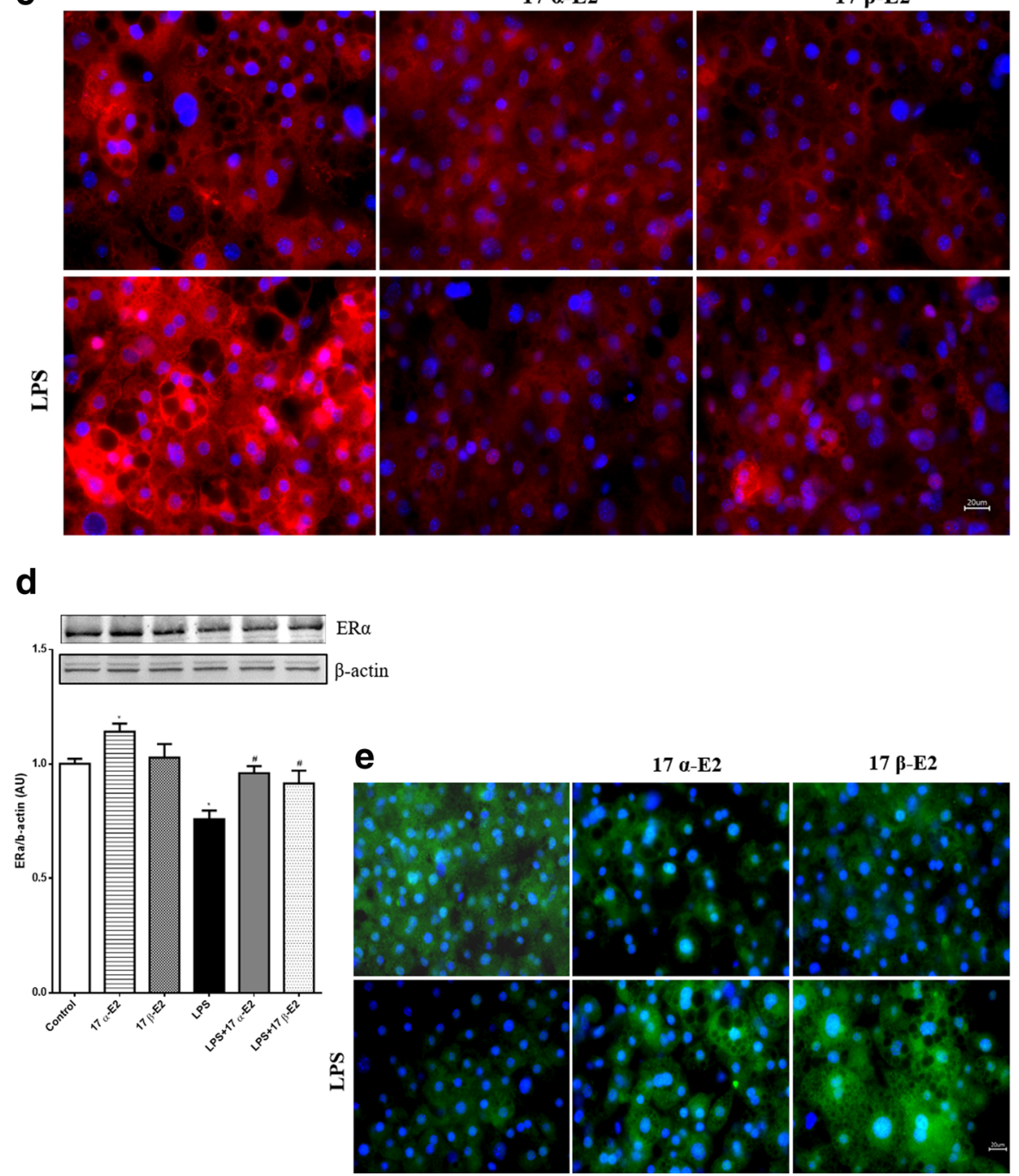

Fig. 7 (See legend on next page.) 
(See figure on previous page.)

Fig. 7 Effects of 17 a-E2 and 17 B-E2 on p65 and ERa protein expression in 3T3-L1 differentiated cells. a Nuclear and cytoplasmic fractions were extracted for Western blotting (WB) detection of p65. $\mathbf{b}$ Total protein was extracted for WB detection of p65. c Microscopy images of immunofluorescence labeling of p65 (red) in 3T3-L1 cells. Nuclei were stained with DAPI. d Total protein was extracted for WB detection of ERa. e Microscopy images of immunofluorescence labeling of ERa (green) in 3T3-L1 cells. Nuclei were stained with DAPI. Data are presented as mean \pm SEM values. Asterisk indicates $P<0.05$ compared to control group (C). Pound indicates $P<0.05 \times$ LPS group. $(n=4$ independent rounds of cells for WB, and $n=3$ independent rounds of cells for immunofluorescence)

p50 or p65 vectors alone induced IL-6 promoter activation. However, treatment of cells with estrogens (E2) abolished the IL- 6 promoter activity, which was similar to the transfection of p50 and p65 with ІкB $\alpha$ construct, which completely abrogated the NFKB-mediated IL-6 promoter activity. When cells were stimulated with phorbol ester (PMA), the levels of cytosolic I $\mathrm{B} \alpha \alpha$ protein were hugely decreased, while when co-treated with E2 and PMB, the PMA-induced IкB $\alpha$ protein degradation was inhibited. One possible explanation is that E2 stabilizes IкB $\alpha$ protein by interfering with its phosphorylation or ubiquination, inhibiting its proteolysis. There was no data in this study regarding which ER was transfected to HeLa cells that was mediating E2's effects.

In the review of Kalaitzidis and Gilmore (2005) [48], the authors discuss that $\mathrm{ER} \alpha$, in an estrogen-dependent manner, inhibits $\mathrm{NF}_{\mathrm{K} B}$ activity in various cell lines, including Hep2, MCF-7, U2-OS, HeLa, F9, 293, and U937, and that this can occur by various mechanisms. One of the mechanisms they suggest is direct binding of ER $\alpha$ to p50/p52 and RelA/c-Rel heterodimers in the nucleus, which in turn blocks the binding of NFKB to the promoter region of target genes, such as the IL- 6 promoter, preventing their transcription. Moreover, E2 binding to ER $\alpha$ can affect IKB processing possibly through E2-mediated inhibition of IkK, which prevents IkB phosphorylation, degradation, and $N F k B$ translocation to the nucleus. ER $\alpha$ can also affect the ability of $\mathrm{NF}_{\mathrm{K}} \mathrm{B}$ to interact with coactivators, either by direct competition or through disruption of the ability of NFKB to bind with coactivators, including Bcl-3, p300, and CBP among others.

The concentration of E2 is important for its ability to modulate NFkB; according to the literature, E2 concentrations equal to or above $100 \mathrm{pM}$ are necessary to inhibit NFKB activation [8]. Additionally, in vitro studies have demonstrated that high concentrations of $17 \beta$-E2 block LPS-induced NFkB-p65 DNA binding and transcriptional activity by preventing its nuclear translocation $[49,50]$. This is important because in our study, we used an elevated concentration $(10 \mu \mathrm{M})$ of both E2s, but they failed to prevent the translocation of the p65 subunit of Nfkb to the nucleus. We attribute the differences to differing cell types, as well as the timing and dosage of LPS/E2 treatments. Although E2s could not prevent the translocation of p65 to the nucleus, we did observe a reduction in p65 protein levels in cells, suggesting that reductions in the amount of $\mathrm{p} 65$ protein available for nuclear translocation may underlie the reduced transcription of pro-inflammatory genes.

It is important to note that the objective of the experiments described here was to directly compare the same concentrations of the different E2s in order to discern differences in their ability to modulate inflammatory markers. The concentration used in these studies was equivalent to the pharmacological dose of $17 \beta$-E2 used in vivo [51, 52]. Currently, the literature is unclear as to whether the concentrations of these estrogenic hormones differ, and more specifically, if they differ by tissue type. Future studies are important to determine circulating and tissue specific levels of these hormones, as well as to test physiological levels of each estrogen to begin to characterize their similarities and differences. This will be extremely important to be done for both sexes, as we predict the tissue levels of these estrogens may differ by sex. This is an emerging field. While we believe we have begun to understand how these hormones function to reduce inflammation, more work is required to mechanistically understand their function at the tissue level.

\section{Conclusions}

In conclusion, we provide new evidence demonstrating an anti-inflammatory role for $17 \alpha$-E2 in adipocytes, which appears to require ER $\alpha$ in females, but not in males. Furthermore, our data suggest a potential mechanism by which $17 \alpha$-E2 provides an anti-inflammatory effect which is by reducing NFKB p65 subunit transcription and translation, which, in turn, decreases transcription of inflammatory markers such as Tnf- $\alpha$ and Il-6. These findings are important because there is increasing interest in attaining the clinical benefits of estrogen compounds while avoiding adverse side effects. Since $17 \alpha$-E2 is a non-feminizing estrogen, its use may not cause the potential deleterious effects of feminizing estrogens. As such, our study suggests that this estrogen may be pharmacologically relevant for treatment of inflammatory diseases in males, as well as in postmenopausal females.

\section{Additional files}

Additional file 1: Figure S1. Effects of $17 \mathrm{a}-\mathrm{E} 2$ and $17 \beta-E 2$ on modulation of viability of cells and lipolysis in 3T3-L1 differentiated cells. (A) Cell viability in $\%$ after estrogens and LPS treatments. (B) Oil red O staining for lipolysis in all groups. Data were presented in mean \pm SEM values. (TIFF $2622 \mathrm{~kb}$ ) 
Additional file 2: Figure S2. Effects of Esr1 silencing on Esr-1 gene and ERa protein expression in 3T3-L1 differentiated cells. (A) Relative mRNA expression of Esr1. (B) Total protein was extracted for Western blotting detection of ERa after $72 \mathrm{~h}$ of siRNA. Data were presented in mean \pm SEM values. Symbol (*) indicates $P<0.05$ compared to control group (C). (\&) indicates $P<0.05 \times$ siRNA group. ( $n=3$ independent rounds of cells). (TIFF $375 \mathrm{~kb}$ )

Additional file 3: Figure S3. mRNA expression of Esr2 (A) and Gper1 (B) in primary pre-adipocyte cells derived from male mice. Data were presented in mean \pm SEM values. Symbol (\&) indicates $P<0.05$ compared to WT mice. ( $n=3$ independent rounds of cells). (TIFF $375 \mathrm{~kb}$ )

Additional file 4: Figure S4. mRNA expression of Esr2 (A) and Gper1 (B) in Mef cells derived from WT and ERKO male mice. Data were presented in mean \pm SEM values. Symbol ( $\&$ indicates $P<0.05$ compared to WT mice. ( $n=3$ independent rounds of cells). (TIFF $239 \mathrm{~kb}$ )

\section{Funding}

This material was based upon work supported by Fundação de Amparo à Pesquisa do Estado de São Paulo (FAPESP), under Grant 2015/05801-7.

\section{Availability of data and materials}

The datasets generated during the current study are available from the corresponding author on reasonable request.

\section{Authors' contributions}

Experiments in vitro were performed by RSS and LAF. Ex vivo experiments were performed by RSS and APF. Gene silencing was performed by LAF and RSS. Gene expression and Western blotting was performed by RSS. Immunofluorescence was performed by LAF and RSS. Statistics were performed by RSS. RSS, LAF, APF, EMC, and DJC designed and discussed the experiments and results. RSS and DJC prepared the manuscript. All authors read and approved the final manuscript.

\section{Ethics approval and consent to participate}

Primary cells were extracted from animals according to the institutional's guidelines.

\section{Consent for publication}

Not applicable.

\section{Competing interests}

The authors declare that they have no competing interests

\section{Publisher's Note}

Springer Nature remains neutral with regard to jurisdictional claims in published maps and institutional affiliations.

\section{Author details}

'Biomedical Sciences Dept, Diabetes and Obesity Research Division, Cedars-Sinai Medical Center, 8700 Beverly Blvd, Los Angeles, CA 90048, USA. ${ }^{2}$ Obesity and Comorbidities Research Center (OCRC), Institute of Biology, State University of Campinas-UNICAMP, Campinas, SP, Brazil.

Received: 25 May 2017 Accepted: 29 August 2017

\section{Published online: 06 September 2017}

\section{References}

1. Viña J, Gambini J, García-García FJ, Rodriguez-Mañas L, Borrás C. Role of oestrogens on oxidative stress and inflammation in ageing. Horm Mol Biol Clin Investig. 2013;16:65-72.

2. Zhu L, Martinez MN, Emfinger CH, Palmisano BT, Stafford JM. Estrogen signaling prevents diet-induced hepatic insulin resistance in male mice with obesity. Am J Physiol Endocrinol Metab. 2014;306:E188-97.

3. Greenberg AS, Obin MS. Obesity and the role of adipose tissue in inflammation and metabolism. Am J Clin Nutr. 2006;83:461S-5S.

4. Nishimura S, Manab I, Nagai R. Adipose tissue inflammation in obesity and metabolic syndrome. Discov Med. 2009;8:55-60.

5. Pfeilschifter J, Köditz R, Pfohl M, Schatz H. Changes in proinflammatory cytokine activity after menopause. Endocr Rev 2002; 23: 90-119.
6. Tofovic SP. Estrogens and development of pulmonary hypertension: interaction of estradiol metabolism and pulmonary vascular disease. J Cardiovasc Pharmacol. 2010;56:696-708.

7. Mauvais-Jarvis F, Clegg DJ, Hevener AL. The role of estrogens in control of energy balance and glucose homeostasis. Endocr Rev. 2013;34:309-38.

8. Straub RH. The complex role of estrogens in inflammation. Endocr Rev. 2007;28:521-74

9. Morselli E, Fuente-Martin E, Finan B, Kim M, Frank A, Garcia-Caceres C, et al. Hypothalamic PGC-1a protects against high-fat diet exposure by regulating ERa. Cell Rep. 2014;9:633-45.

10. Drew BG, Hamidi H, Zhou Z, Villanueva CJ, Krum SA, Calkin AC, et al. Estrogen receptor (ER)a-regulated lipocalin 2 expression in adipose tissue links obesity with breast cancer progression. J Biol Chem. 2015;290:5566-81.

11. Stein $B$, Yang MX. Repression of the interleukin-6 promoter by estrogen receptor is mediated by NF-kappa B and C/EBP beta. Mol Cell Biol. 1995;15:4971-9.

12. Srivastava S, Weitzmann MN, Cenci S, Ross FP, Adler S, Pacifici R. Estrogen decreases TNF gene expression by blocking JNK activity and the resulting production of c-Jun and JunD. J Clin Invest. 1999;104:503-13.

13. Marino M, Galluzzo P, Ascenzi P. Estrogen signaling multiple pathways to impact gene transcription. Curr Genomics. 2006;7:497-508.

14. Monteiro R, Teixeira D, Calhau C. Estrogen signaling in metabolic inflammation. Mediat Inflamm. 2014;2014:615917.

15. Moos WH, Dykens JA, Nohynek D, Rubinchik E, Howell N. Review of the effects of 17a-estradiol in humans: a less feminizing estrogen with neuroprotective potential. Drug Dev Res. 2009;70:1-21.

16. Toran-Allerand CD. Estrogen and the brain: beyond ER-alpha, ER-beta, and 17beta-estradiol. Ann N Y Acad Sci. 2005;1052:136-44.

17. Schott EW, Katzman PA. Separation and estimation of 17-alpha-estradiol. Endocrinol. 1964;74:870-7.

18. Luukkainen T, Adlercreutz H. Isolation and identification of 11-dehydroestradiol-17a, a new type of urinary steroid, in the urine of pregnant women. Biochim Biophys Acta. 1965;107:579-92.

19. Lippert C, Seeger H, Wallwiener D, Mueck AO. Comparison of the effects of 17alpha-ethinylestradiol and 17beta-estradiol on the proliferation of human breast cancer cells and human umbilical vein endothelial cells. Clin Exp Obstet Gynecol 2002; 29: 87-90.

20. Stout MB, Steyn FJ, Jurczak MJ, Camporez JG, Zhu Y, Hawse JR, et al. 17a-Estradiol alleviates age-related metabolic and inflammatory dysfunction in male mice without inducing feminization. J Gerontol A Biol Med Sci. 2017;72:3-15

21. Dulos J, Vijn P, van Doorn C, Hofstra CL, Veening-Griffioen D, de Graaf J, et al. Suppression of the inflammatory response in experimental arthritis is mediated via estrogen receptor alpha but not estrogen receptor beta. Arthritis Res Ther. 2010;12:R101.

22. Subramanian S, Tovey M, Afentoulis M, Krogstad A, Vandenbark AA, Offner $\mathrm{H}$. Ethinyl estradiol treats collagen-induced arthritis in DBA/1LacJ mice by inhibiting the production of Tnf-a and IL-1beta. Clin Immunol. 2005;115:162-72.

23. Silvestri A, Gebara O, Vitale C, Wajngarten M, Leonardo F, Ramires JA, et al. Increased levels of $C$-reactive protein after oral hormone replacement therapy may not be related to an increased inflammatory response. Circulation. 2003;107:3165-9.

24. Divani AA, Luo X, Datta YH, Flaherty JD, Panoskaltsis-Mortari A. Effect of oral and vaginal hormonal contraceptives on inflammatory blood biomarkers. Mediat Inflamm. 2015:2015:379501.

25. Dykens JA, Moos WH, Howell N. Development of 17alpha-estradiol as a neuroprotective therapeutic agent: rationale and results from a phase I clinical study. Ann N Y Acad Sci. 2005;1052:116-35.

26. Toran-Allerand CD, Tinnikov AA, Singh RJ, Nethrapalli IS. 17alpha-estradiol: a brain-active estrogen? Endocrinology. 2005;146:3843-50.

27. Russo J, Fernandez SV, Russo PA, Fernbaugh R, Sheriff FS, Lareef HM, et al. 17-Beta-estradiol induces transformation and tumoregenesis in human breast epitelial cells. FASEB J. 2006;20:1622-34.

28. Lumachi F, Brunello A, Maruzzo M, Basso U, Basso SM. Treatment of estrogen receptor-positive breast cancer. Curr Med Chem. 2013;20:596-604.

29. Brinton LA, Felix AS. Menopause hormone therapy and risk of endometrial cancer. J Steroid Biochem Mol Biol. 2014;142:83-9.

30. Kaklamani VG, Gradishar WJ. Endocrine therapy in the current management of postmenopausal estrogen receptor-positive metastatic breast cancer. Oncologist 2017 [Epub ahead of print]. 
31. Dupont S, Krust A, Gansmuller A, Dierich A, Chambon P, Mark M. Effect of single and compound knockouts of estrogen receptors alpha (ERalpha) and beta (ERbeta) on mouse reproductive phenotypes. Development (Cambridge, England). 2000;127:4277-91.

32. Kim M, Neinast MD, Frank AP, Sun K, Park J, Zehr JA, et al. ERa upregulates Phd3 to ameliorate HIF-1 induced fibrosis and inflammation in adipose tissue. Mol Metab. 2014 Jun 7;3(6):642-51.

33. Zebisch $\mathrm{K}$, Voigt $\mathrm{V}$, Wabitsch $\mathrm{M}$, Brandsch $\mathrm{M}$. Protocol for effective differentiation of 3T3-L1 cells to adipocytes. Anal Biochem. 2012;425:88-90.

34. Desjardins $\mathrm{P}$, Conklin D. NanoDrop microvolume quantitation of nucleic acids. J Vis Exp. 2010;22:2565.

35. Silva JL, Giannocco G, Furuya DT, Lima GA, Moraes PA, Nachef S, et al. NK-kappaB, MEF2A, MEF2D and HIF1-a involvement on insulin- and contraction-induced regulation of GLUT4 gene expression in soleus muscle. Mol Cell Endocrinol. 2005;240:82-93.

36. Cumming G, Fidler F, Vaux DL. Error bars in experimental biology. J Cell Biol. 2007;177:7-11

37. Lazic SE. The problem of pseudoreplication in neuroscientific studies: is it affecting your analysis? BMC Neurosci. 2010;11:5.

38. Hsu SM, Chen YC, Jiang MC. 17 Beta-estradiol inhibits tumor necrosis factor-alpha-induced nuclear factor-kappa B activation by increasing nuclear factor-kappa B p105 level in MCF-7 breast cancer cells. Biochem Biophys Res Commun. 2000;279:47-52.

39. Pansiot J, Mairesse J, Baud O. Protecting the developing brain by 173 estradiol. Oncotarget 2017 [Epub ahead of print].

40. Rodriques MF, Ferreira FC, Silva-Magosso NS, Barbosa MR, Souza MV Domingos MM et al. Effects of resistance training and estrogen replacement on adipose tissue inflammation in ovariectomized rats. Appl Physiol Nutr Metab 2017 [Epub ahead of print].

41. Stubbins RE, Najjar K, Holcomb VB, Hong J, Núñez NP. Estrogen alters adipocyte biology and protects female mice from adipocyte inflammation and insulin resistance. Diabetes Obes Metab. 2012;14:58-66.

42. Davis KE, D Neinast M, Sun K, M Skiles W, D Bills J, A Zehr J, et al. The sexually dimorphic role of adipose and adipocyte estrogen receptors in modulating adipose tissue expansion, inflammation, and fibrosis. Mol Met. 2013;2:227-42.

43. Edwards DP. McGuire WL. 17 Alpha-Estradiol is a biologically active estrogen in human breast cancer cells in tissue culture. Endocrinology. 1980;107:884-91.

44. Kuiper GG, Carlsson B, Grandien K, Enmark E, Häggblad J, Nilsson S, et al. Comparison of the ligand binding specificity and transcript tissue distribution of estrogen receptors alpha and beta. Endocrinology. 1997:138:863-70.

45. Kaur SP, Bansal S, Chopra K. 17a-Estradiol: a candidate neuroserm and non-feminizing estrogen for postmenopausal neuronal complications. Steroids. 2015;96:7-15.

46. Quaedackers ME, Van Den Brink CE, Wissink S, Schreurs RH, Gustafsson JA, Van Der Saag PT, et al. 4-Hydroxytamoxifen trans-represses nuclear factor-kappa B activity in human osteoblastic U2-OS cells through estrogen receptor (ER)alpha, and not through ER beta. Endocrinology. 2001;142:1156-66.

47. Sun WH, Keller ET, Stebler BS, Ershler WB. Estrogen inhibits phorbol ester-induced I kappa B alpha transcription and protein degradation. Biochem Biophys Res Commun. 1998;244:691-5.

48. Kalaitzidis D, Gilmore TD. Transcription factor cross-talk: the estrogen receptor and NF-kappaB. Trends Endocrinol Metab. 2005;16:46-52.

49. Dodel RC, Du Y, Bales KR, Gao F, Paul SM. Sodium salicylate and 17betaestradiol attenuate nuclear transcription factor NF-kappaB translocation in cultured rat astroglial cultures following exposure to amyloid A beta(1-40) and lipopolysaccharides. J Neurochem. 1999;73:1453-60.

50. Ghisletti S, Meda C, Maggi A, Vegeto E. 17beta-Estradiol inhibits inflammatory gene expression by controlling NF-kappaB intracellular localization. Mol Cell Biol. 2005:25:2957-68.

51. Adams KL, Maxson MM, Mellander L, Westerink RH, Ewing AG. Estradiol inhibits depolarization-evoked exocytosis in PC12 cells via N-type voltage-gated calcium channels. Cell Mol Neurobiol. 2010;30:1235-42.

52. Ma YL, Qin P, Li Y, Shen L, Wang SQ, Dong HL, et al. The effects of different doses of estradiol (E2) on cerebral ischemia in an in vitro model of oxygen and glucose deprivations and reperfusion and a rat model of middle carotid artery occlusion. BMC Neurosci. 2013;14:118.

\section{Submit your next manuscript to BioMed Central and we will help you at every step:}

- We accept pre-submission inquiries

- Our selector tool helps you to find the most relevant journal

- We provide round the clock customer support

- Convenient online submission

- Thorough peer review

- Inclusion in PubMed and all major indexing services

- Maximum visibility for your research

Submit your manuscript at www.biomedcentral.com/submit
Biomed Central 